\title{
IMPACT OF PACKAGING AND HEAT TREATMENT ON MAINTAINING GREEN ONION POST HARVEST QUALITY
}

\author{
EMAM, M. S.
}

Post harvest and handling of vegetable crops department. Hort .Res. Inst., ARC, Giza

(Manuscript received 3 December 2008)

\begin{abstract}
Packaging film and heat treatments were tested as means to maintain quality and extend the shelf life of green onion plants (Allium cepa) cv. Giza 20. Packaging in nonperforated polyethylene bags maintained the visual quality appearance, chlorophyll content of the green leaves and reduced weight loss percentage when stored at $0^{\circ} \mathrm{C}$ followed by 2 days at $20^{\circ} \mathrm{C}$ simulated retail period.

Total soluble solids did not affect by packaging type. However, hot water treatment $55^{\circ} \mathrm{C}$ for 6 min controlled leaf growth and reduced curvature. Also, stored the plants vertically reduced subsequent green onion geotropic curvature but did not affect the extension leaf growth.
\end{abstract}

\section{INTRODUCTION}

Minimal or fresh-cut processing of green onion provides convenience to food service and retail customers but may result in limited postcutting shelf life because of undesirable physiological changes (Cantwell et al., 2001). Minimal processing of green onion includes removal senescent and damaged outer leaves, the cutting of roots, trimming of the leaves to give plants of $30 \mathrm{~cm}$ length. This preparation usually results in cutting damage, discoloration, dehydration and decay which are common defects of the cut surface (Hong et al., 2000).

Extention growth of the white inner leaf bases (Cantwell et al., 2001) and leaf curvature due to negative geotropism which occurs when the product is placed horizontally (Hong et al., 2000) causes a rapid loss in the overall market quality of the product. Thus, for this reason, this work was undertaken to study the potential benefit of packaging film, hot water treatment and plant position inside the package on the maintenance of quality, reducing extension growth and geotropic curvature of green onion during cold storage and shelf life conditions.

Packaging film has been used with low temperature storage to maintain green onion fresh appearance (Atta-Aly, 1998), reduced weight loss (Jacxsens et al., 2002) and slowed down the loss of color (Hruschka, 1974). Packaging green onion in polypropylene bag is very important to protect the marketability of the plant (Emam, 1999). 
Heat treatment have been demonstrated to be effective as a non chemical means for quality retention of fresh horticultural products. Hot water dip was more effective in reducing extension growth of green onion (Hong et al., 2000, Cantwell et al., 2001) and controlled geotropic curvature in green onion (Hong et al., 2000).

Packaging and shipping of asparagus spear vertically can be considered as useful tool to reduce geotropic bending (Paull and Chen., 1999).

\section{MATERIALS AND METHODS}

Green onion (Allium cepa, L.) seeds Cv. Giza 20, were sown on $19^{\text {th }}$ of October of both 2005 and 2006 seasons, at Kaha Experimental Farm, Qalubia Governorate using standard production practices.

After 3 months from planting, the plants were harvested on January $22^{\text {nd }}$ and $24^{\text {th }}$ of 2006 and 2007 seasons respectively. Plants were transferred directly to the laboratory of Post harvest and Handling Research Department at Giza Governorate under cooling. Plants were trimmed (leaf tips and root cut) and sorted in uniform size (10-17 mm bulb diameter and $25 \mathrm{~cm}$ length). Defect free plants were bunched (10 plants/bunch) and tied using rubber bands. The bunches were divided into two groups for the following experiments:

\section{The first experiment:}

\section{Effect of packaging type}

Green onion plants were packed in the following procedures:

1- Packing every two bunches in non perforated polyethylene bags 30 micron thickness and $30 \times 15 \mathrm{~cm}$ in size.

2- Packing every two bunches in perforated polypropylene bags 0.09 micron thickness and $30 \times 15 \mathrm{~cm}$ in size.

3- Packing the plants with gel ice.

4- Unpackaged plants (control).

\section{The second experiment}

\section{Effect of hot water treatment and plant position}

Green onion plants were dipped in hot water from the lower $5 \mathrm{~cm}$ of the white stem base as follows

$1-55^{\circ} \mathrm{C}$ for $6 \mathrm{~min} . \quad-2-47^{\circ} \mathrm{C}$ for $4 \mathrm{~min}$.

After the heat treatment, the plants were cooled by immersion in cool water.

3 - Plants were placed vertically inside carton box

4 - Plants were placed horizontally inside carton box (control) 
Experiments were arranged in completely randomized design. Fourteen punches were put in carton box as one replicate. Twelve replicates for each treatment were stored at $0^{\circ} \mathrm{C}$ and $90-95 \mathrm{RH}$ for 16 days. Three replicates were removed every 4 days intervals and placed at $20^{\circ} \mathrm{C}$ for 2 subsequent days to simulate retail market, and examined for quality measurements.

\section{Quality evaluations}

\section{a- Physical determinations}

1- Overall visual quality was scored on a 9-1 scale, with reference points of 9 excellent, 7 good, 5 fair, 3 poor and 1 unusable. The visual quality included symptoms and rate of deterioration (leaf tip dryness, leaf witting, yellowing and curvature defects (Hong et al., 2000).

2- Percentage of weight loss was determined as :

$=\frac{\text { Weight of sample at the beginning of storage }- \text { its weight after storage }}{\text { weight of sample at the beginning of storage }} \times 100$

3- Inner leaf extension was measured with a vernier caliper, considering the growth of leaves from the $25 \mathrm{~cm}$ initial plant length to the upper leaflet and expressed in $\mathrm{mm}$.

4- Curvature score of 1-5 was used where $1=$ none, 2 curvature of stem or leaf up to $15^{\circ}$ from the horizontal position, $3,15-30^{\circ}, 4,30-45^{\circ}$ and $5,>45^{\circ}$ (Hong et al., 2000).

\section{Chemical determinations:}

1- Total soluble solids\% was determined by using hand rafractometer (A.O.A.O, 1990).

2- Dry matter\% was determined by weigh $100 \mathrm{gm}$ of fresh weight and dried at $70^{\circ} \mathrm{C}$ until a constant weight was reached.

3- Titratable acidity was quantified by titrating against $0.01 \mathrm{~N} \mathrm{NaOH}$ with phenol phethalin as an indicator and expressed as $\mathrm{mg} / 100 \mathrm{gm}$ fresh weight (A.O.A.C, 1990).

4- Total chlorophyll was measured using Minolta chlorophyll meter spad.

All the data were subjected to the statistical analysis according to the method described by Snedecor and Cochran (1980). 


\section{RESULTS AND DISCUSSION}

\subsection{Effect of packaging type}

\subsection{1: Effect of packaging type}

Packaging of green onion plants resulted in a significantly higher visual quality score as compared to unpacked control (Table 1). Green onion plants packed in unperforated poly ethylene (P.E) bags had the superior score followed by perforated polypropylene bags in the two seasons. Unpackaged onion plants had the lower visual quality score. It seems that the higher relative humidity created within packages film reduces moisture loss and maintaining the fresh appearance of green onion plant (Atta-Aly, 1998, In and Man, 2004 on green onion).

The results in Table (1) demonstrate that the unpackaged green onion plants control resulted significant higher weight loss (11.23\%) when compared with the other packaging types whereas the least loss in weight obtained from non perforated polyethylene and perforated polypropylene bags respectively in the two seasons. These results confirming the previous reports about packing film effects on reducing water loss in green onion (Atta-Aly, 1998, Emam, 1999).

Packaging type had non significant effect on dry matter content after cold storage at $0^{\circ} \mathrm{C}$ and holding at $20^{\circ} \mathrm{C}$ simulated retail period in the first season while significant effect was noticed in the second season pointing that, un packaged control and non-perforated polyethylene bag had the higher dry matter content (Table 1).

No significant differences in total soluble solids content among packaging type and those unpackaged were detected in the both seasons of study (Table 1).

Table 1. Effect of packaging type on the physical and chemical properties of green onion plants during storage in 2005-2006 and 2006-2007 seasons.

\begin{tabular}{|c|c|c|c|c|c|c|}
\hline Packaging type & $\begin{array}{l}\text { Visual } \\
\text { quality } \\
\text { (score) }\end{array}$ & $\begin{array}{l}\text { Weight } \\
\text { loss } \\
(\%)\end{array}$ & $\begin{array}{l}\text { Dry } \\
\text { matter } \\
(\%)\end{array}$ & $\begin{array}{c}\text { Total } \\
\text { soluble } \\
\text { solids } \\
(\%)\end{array}$ & $\begin{array}{l}\text { Chlorophyll } \\
\text { (spad) }\end{array}$ & $\begin{array}{c}\text { Titratable } \\
\text { acidity } \\
\text { (mg/100g.f.w) }\end{array}$ \\
\hline \multicolumn{7}{|c|}{$2005-2006$} \\
\hline Non perforated poly ethylene bag & 8.19 & 0.44 & 13.52 & 9.12 & 47.72 & 0.24 \\
\hline Perforated polyproplene bag & 7.79 & 0.91 & 13.35 & 8.84 & 45.77 & 0.23 \\
\hline Packaging with gel ice & 7.66 & 6.51 & 13.44 & 9.13 & 46.35 & 0.23 \\
\hline Unpackaged plant control & 6.33 & 11.23 & 13.73 & 9.03 & 43.56 & 0.22 \\
\hline L.S.D at $5 \%$ & 0.57 & 0.59 & N.S & N.S & 2.39 & 0.000233 \\
\hline \multicolumn{7}{|c|}{$2006-2007$} \\
\hline Non perforated poly ethylene bag & 7.79 & 0.51 & 12.77 & 8.49 & 50.58 & 0.25 \\
\hline Perforated polyproplene bag & 7.26 & 0.99 & 12.58 & 8.35 & 49.26 & 0.25 \\
\hline Packaging with gel ice & 7.04 & 6.44 & 12.59 & 8.50 & 49.21 & 0.25 \\
\hline Unpackaged plant control & 6.46 & 11.69 & 13.09 & 8.50 & 45.97 & 0.23 \\
\hline L.S.D at $5 \%$ & 0.63 & 1.18 & 0.48 & N.S & 2.63 & 0.000233 \\
\hline
\end{tabular}


Packaging types induced higher chlorophyll content in the green leaves after cold storage and simulated retail market as compared with the unpackaged control (Table, 1). This results confirmed with those obtained by Atta-Aly, 1998 and Emam,1999 on green onion.

Packaging green onion plants in non perforated polyethylene bags resulted in significant higher titratable acidity as compared to the un-packaged control. These findings were similar to those found by Atta-Aly,1998, and Emam, 1999.

\subsubsection{Effect of storage period:}

Visual quality decreased significantly during storage. After 8 days in cold storage plus 2 days at $20^{\circ} \mathrm{C}$ visual quality score was (7.46) while after 16 days in cold storage plus additional 2 days at $20^{\circ} \mathrm{C}$, visual quality score reached (5.92) in the first season (Table, 2) and similar results was found in the second season.

Table 2. Effect of storage period on the physical and chemical properties of green onion plants during storage in 2005-2006 and 2006-2007 seasons

\begin{tabular}{|l|c|c|c|c|c|c|}
\hline \multicolumn{1}{|c|}{$\begin{array}{c}\text { Storage period } \\
\text { (days) }\end{array}$} & $\begin{array}{c}\text { Visual } \\
\text { quality } \\
(\text { score })\end{array}$ & $\begin{array}{c}\text { Weight } \\
\text { loss } \\
(\%)\end{array}$ & $\begin{array}{c}\text { Dry } \\
\text { matter } \\
(\%)\end{array}$ & $\begin{array}{c}\text { Total } \\
\text { soluble } \\
\text { solids } \\
(\%)\end{array}$ & $\begin{array}{c}\text { Chlorophyll } \\
\text { (spad) }\end{array}$ & $\begin{array}{c}\text { Titratable } \\
\text { acidity } \\
(\mathrm{mg} / 100 \mathrm{~g} . f . w)\end{array}$ \\
\hline At harvest & 9.00 & 0.00 & 13.63 & 9.33 & 51.40 & 0.26 \\
\hline $4 \mathrm{~d}$ at $0^{\circ} \mathrm{C}+2 \mathrm{~d}$ at $20^{\circ} \mathrm{C}$ & 8.50 & 2.63 & 13.81 & 9.39 & 48.55 & 0.24 \\
\hline $8 \mathrm{~d}$ at $0^{\circ} \mathrm{C}+2 \mathrm{~d}$ at $20^{\circ} \mathrm{C}$ & 7.46 & 3.95 & 13.71 & 9.19 & 45.85 & 0.23 \\
\hline $12 \mathrm{~d}$ at $0^{\circ} \mathrm{C}+2 \mathrm{~d}$ at $20^{\circ} \mathrm{C}$ & 6.62 & 5.51 & 13.41 & 8.85 & 43.16 & 0.22 \\
\hline $16 \mathrm{~d}$ at $0^{\circ} \mathrm{C}+2 \mathrm{~d}$ at $20^{\circ} \mathrm{C}$ & 5.92 & 6.99 & 13.01 & 8.39 & 40.28 & 0.20 \\
\hline L.S.D at $5 \%$ & 0.63 & 0.59 & 0.45 & 0.38 & 2.67 & 0.000261 \\
\hline \multicolumn{7}{|c|}{$2006-2007$} \\
\hline At harvest & 9.00 & 0.00 & 12.89 & 8.67 & 54.67 & 0.27 \\
\hline $4 \mathrm{~d}$ at $0^{\circ} \mathrm{C}+2 \mathrm{~d}$ at $20^{\circ} \mathrm{C}$ & 8.25 & 2.76 & 13.06 & 8.67 & 51.40 & 0.26 \\
\hline $8 \mathrm{~d}$ at $0^{\circ} \mathrm{C}+2 \mathrm{~d}$ at $20^{\circ} \mathrm{C}$ & 7.38 & 4.53 & 12.95 & 8.59 & 49.20 & 0.25 \\
\hline $12 \mathrm{~d}$ at $0^{\circ} \mathrm{C}+2 \mathrm{~d}$ at $20^{\circ} \mathrm{C}$ & 6.25 & 5.57 & 12.62 & 8.29 & 45.85 & 0.23 \\
\hline $16 \mathrm{~d}$ at $0^{\circ} \mathrm{C}+2 \mathrm{~d}$ at $20^{\circ} \mathrm{C}$ & 4.83 & 6.75 & 12.28 & 8.11 & 42.67 & 0.21 \\
\hline L.S.D at $5 \%$ & 0.70 & 1.18 & 0.54 & 0.36 & 2.94 & 0.000261 \\
\hline
\end{tabular}

Stored green onion plants showed significant weight loss as the storage period extended. After 16 days in cold storage and 2-subsequent days at $20^{\circ} \mathrm{C}$, weight loss reached $(6.99 \%)$. in the first season and similar trend was found in the second one. This continuous loss in weight during storage and shelf life resulted from the loss of water by transpiration and dry matter by respiration (Atta-Aly, 1998 on green onion).

Holding green onion plant in cold storage for 16 days plus 2 additional days at $20^{\circ} \mathrm{C}$ resulted in significant continuously loss in dry matter except after 4 days which gave slight increase as a result of more water loss and less 
consumption of dry matter content (carbohydrates) as compared to that at harvest time in the two seasons. (Table, 2).

A significant decrease in total soluble solids content was noticed with the advancement of the storage period in both seasons. T.S.S. followed the same trend in dry matter which increased after the $4^{\text {th }}$ day of cold storage and then started to decrease due to the effects of the previous reasons mentioned before. The changes in T.S.S at the various storage periods is the resultant of movement of water and soluble solids to and from the plant, the inversion of insoluble solids compound to simpler soluble solids forms and the use of these chemicals during respiration. The prevalence of one or more of these factors during plant growth may accumulate or lessen these contents (Hulme, 1970).

Storing green onion plant for 16 days at $0^{\circ} \mathrm{C}$ plus 2 subsequent days at $20^{\circ} \mathrm{C}$ resulted in significant loss in chlorophyll content compared to that found at harvest time found in the two seasons (Table, 2). The reduction in chlorophyll content with the elapse of the storage period may be due to the destruction of the chlorophyll and transformation of chloroplasts to chromoplasts by chlorophyllase activity (Hulme,1970).

A general trend of decrease in titratable acidity took place till the last storage period (Table, 2) The progressive consumption of organic reserves of harvested plant induced a loss of quality and a reduction of their shelf life. Aerobic respiration involves oxidation of organic compounds by enzymatic reaction with production of $\mathrm{CO}_{2}$ and water vapor and release of free energy. Consequently respiration is one of the most important factors for keeping quality of vegetables. In fact, decreased respiration activity is usually a good index to the increased shelf life (Artes, 2002).

\subsection{3: Effect of interaction between packaging type $x$ storage period.}

Green onion plants from all packaging types significantly lost visual quality score after cold storage and retail market simulation, after 16 days of cold storage and 2 subsequent days at $20^{\circ} \mathrm{C}$ (Table, 3). However, in spite of, the continuous visual quality loss, green onion plants still good after 8 days at $0^{\circ} \mathrm{C}+2$ days at $20^{\circ} \mathrm{C}$ when packed in the sealed P.E.B and perforated poly propylene bags or with gel ice while unpacked plants had the least score, especially at the end of storage in the two seasons. Interaction effects between packaging types and storage period appeared significant in both seasons for dry matter and total soluble solids contents (Table, 3). However, after 16 days of cold storage plus 2-subsequent days at $20^{\circ} \mathrm{C}$, non perforated polyethylene bag had higher values of chlorophyll and titratable acidity than the other packaging types (Table, 3).

From the previous results, it could be concluded that packaging green onion plants in non perforated poly ethylene bags was the most effective in reducing weight loss and maintain the green colour of the leaves during storage beside induced good visual quality after 16 days of cold storage at $0^{\circ} \mathrm{C}$ plus 2 days at $20^{\circ} \mathrm{C}$. 
Table 3. Effect of interaction between packaging type and storage period on the physical and chemical properties of green onion plants during storage in $2005-2006$ and $2006-2007$ seasons

\begin{tabular}{|c|c|c|c|c|c|c|c|c|c|c|c|c|c|}
\hline \multirow[t]{3}{*}{$\begin{array}{l}\text { Packaging } \\
\text { type }\end{array}$} & \multirow[t]{2}{*}{$\begin{array}{l}\text { Storage period } \\
\quad \text { (days) }\end{array}$} & $\begin{array}{l}\text { Visual } \\
\text { quality } \\
\text { (score) }\end{array}$ & $\begin{array}{c}\text { Weight } \\
\text { loss } \\
(\%)\end{array}$ & $\begin{array}{c}\text { Dry } \\
\text { matter } \\
(\%)\end{array}$ & $\begin{array}{c}\text { Total soluble } \\
\text { solids } \\
(\%)\end{array}$ & $\begin{array}{c}\text { Chlorophyll } \\
\text { (spad) }\end{array}$ & $\begin{array}{c}\text { Titratable } \\
\text { acidity } \\
\text { (mg/100g.f.w) }\end{array}$ & $\begin{array}{l}\text { Visual } \\
\text { quality } \\
\text { (score) }\end{array}$ & $\begin{array}{c}\text { Weight } \\
\text { loss } \\
(\%)\end{array}$ & $\begin{array}{c}\text { Dry } \\
\text { matter } \\
(\%)\end{array}$ & $\begin{array}{c}\text { Total } \\
\text { soluble } \\
\text { solids } \\
(\%)\end{array}$ & $\begin{array}{l}\text { Chlorophyll } \\
\text { (spad) }\end{array}$ & $\begin{array}{c}\text { Titratable } \\
\text { acidity } \\
\text { (mg/100g.f.w) }\end{array}$ \\
\hline & & \multicolumn{6}{|c|}{$2005-2006$} & \multicolumn{6}{|c|}{$2006-2007$} \\
\hline & At harvest & 9.00 & 0.00 & 13.63 & 9.33 & 51.40 & 0.26 & 9.00 & 0.00 & 12.89 & 8.67 & 54.67 & 0.27 \\
\hline \multirow{4}{*}{$\begin{array}{c}\text { Non perforated } \\
\text { polyethylene } \\
\text { bag }\end{array}$} & $4 \mathrm{~d}$ at $0^{\circ} \mathrm{C}+2 \mathrm{~d}$ at $20^{\circ} \mathrm{C}$ & 9.00 & 0.28 & 13.76 & 9.20 & 50.80 & 0.25 & 9.00 & 0.34 & 13.01 & 8.60 & 53.80 & 0.27 \\
\hline & $8 \mathrm{~d}$ at $0^{\circ} \mathrm{C}+2 \mathrm{~d}$ at $20^{\circ} \mathrm{C}$ & 8.33 & 0.34 & 13.62 & 9.23 & 48.40 & 0.24 & 8.33 & 0.41 & 12.87 & 8.66 & 51.20 & 0.26 \\
\hline & $12 \mathrm{~d}$ at $0^{\circ} \mathrm{C}+2 \mathrm{~d}$ at $20^{\circ} \mathrm{C}$ & 7.66 & 0.48 & 13.43 & 9.03 & 45.40 & 0.23 & 7.00 & 0.59 & 12.66 & 8.33 & 48.20 & 0.24 \\
\hline & $16 \mathrm{~d}$ at $0^{\circ} \mathrm{C}+2 \mathrm{~d}$ at $20^{\circ} \mathrm{C}$ & 7.00 & 0.65 & 13.16 & 8.80 & 42.60 & 0.22 & 5.66 & 0.70 & 12.43 & 8.20 & 45.03 & 0.23 \\
\hline & At harvest & 9.00 & 0.00 & 13.63 & 9.33 & 51.40 & 0.26 & 9.00 & 0.00 & 12.89 & 8.67 & 54.67 & 0.27 \\
\hline \multirow{4}{*}{$\begin{array}{l}\text { perforated } \\
\text { polyproplene } \\
\text { bag }\end{array}$} & $4 \mathrm{~d}$ at $0^{\circ} \mathrm{C}+2 \mathrm{~d}$ at $20^{\circ} \mathrm{C}$ & 9.00 & 0.38 & 13.70 & 9.33 & 48.20 & 0.24 & 8.33 & 0.52 & 12.94 & 8.52 & 51.30 & 0.26 \\
\hline & $8 \mathrm{~d}$ at $0^{\circ} \mathrm{C}+2 \mathrm{~d}$ at $20^{\circ} \mathrm{C}$ & 7.66 & 0.64 & 13.43 & 8.86 & 45.30 & 0.23 & 7.66 & 0.90 & 12.81 & 8.20 & 50.80 & 0.25 \\
\hline & $12 \mathrm{~d}$ at $0^{\circ} \mathrm{C}+2 \mathrm{~d}$ at $20^{\circ} \mathrm{C}$ & 7.00 & 1.09 & 13.17 & 8.56 & 43.43 & 0.22 & 6.33 & 1.10 & 12.31 & 8.25 & 46.50 & 0.23 \\
\hline & $16 \mathrm{~d}$ at $0^{\circ} \mathrm{C}+2 \mathrm{~d}$ at $20^{\circ} \mathrm{C}$ & 6.33 & 1.52 & 12.84 & 8.13 & 40.50 & 0.20 & 5.00 & 1.42 & 11.95 & 8.13 & 43.03 & 0.22 \\
\hline & At harvest & 9.00 & 0.00 & 13.63 & 9.33 & 51.40 & 0.26 & 9.00 & 0.00 & 12.89 & 8.67 & 54.67 & 0.27 \\
\hline \multirow{4}{*}{$\begin{array}{c}\text { packaging } \\
\text { with } \\
\text { gel ice }\end{array}$} & $4 \mathrm{~d}$ at $0^{\circ} \mathrm{C}+2 \mathrm{~d}$ at $20^{\circ} \mathrm{C}$ & 9.00 & 3.06 & 13.81 & 9.50 & 48.50 & 0.24 & 8.00 & 3.21 & 13.00 & 8.80 & 51.80 & 0.26 \\
\hline & $8 \mathrm{~d}$ at $0^{\circ} \mathrm{C}+2 \mathrm{~d}$ at $20^{\circ} \mathrm{C}$ & 7.50 & 5.11 & 13.57 & 9.45 & 46.10 & 0.23 & 7.20 & 5.70 & 12.73 & 8.66 & 49.60 & 0.25 \\
\hline & $12 \mathrm{~d}$ at $0^{\circ} \mathrm{C}+2 \mathrm{~d}$ at $20^{\circ} \mathrm{C}$ & 6.80 & 7.69 & 13.28 & 8.89 & 44.30 & 0.22 & 6.00 & 7.13 & 12.33 & 8.26 & 46.40 & 0.23 \\
\hline & $16 \mathrm{~d}$ at $0^{\circ} \mathrm{C}+2 \mathrm{~d}$ at $20^{\circ} \mathrm{C}$ & 6.00 & 10.19 & 12.91 & 8.50 & 41.43 & 0.21 & 5.00 & 9.70 & 12.00 & 8.13 & 43.60 & 0.22 \\
\hline & At harvest & 9.00 & 0.00 & 13.63 & 9.33 & 51.40 & 0.26 & 9.00 & 0.00 & 12.89 & 8.67 & 54.67 & 0.27 \\
\hline \multirow{4}{*}{ un packaged } & $4 \mathrm{~d}$ at $0^{\circ} \mathrm{C}+2 \mathrm{~d}$ at $20^{\circ} \mathrm{C}$ & 7.00 & 6.80 & 13.97 & 9.53 & 46.70 & 0.24 & 7.66 & 7.00 & 13.27 & 8.75 & 48.70 & 0.24 \\
\hline & $8 \mathrm{~d}$ at $0^{\circ} \mathrm{C}+2 \mathrm{~d}$ at $20^{\circ} \mathrm{C}$ & 6.33 & 9.71 & 14.20 & 9.23 & 43.60 & 0.22 & 6.33 & 11.10 & 13.40 & 8.81 & 45.20 & 0.23 \\
\hline & $12 \mathrm{~d}$ at $0^{\circ} \mathrm{C}+2 \mathrm{~d}$ at $20^{\circ} \mathrm{C}$ & 5.00 & 12.80 & 13.73 & 8.92 & 39.50 & 0.198 & 5.66 & 13.46 & 13.15 & 8.32 & 42.30 & 0.21 \\
\hline & $16 \mathrm{~d}$ at $0^{\circ} \mathrm{C}+2 \mathrm{~d}$ at $20^{\circ} \mathrm{C}$ & 4.33 & 15.60 & 13.11 & 8.13 & 36.60 & 0.183 & 3.66 & 15.20 & 12.72 & 7.95 & 39.00 & 0.19 \\
\hline L.S.D at $5 \%$ & & 1.27 & 1.19 & 0.90 & 0.77 & 5.35 & 0.000522 & 1.41 & 2.37 & 1.09 & 0.73 & 5.89 & 0.000522 \\
\hline
\end{tabular}




\subsection{Effect of heat treatment and plants position}

\subsubsection{Effect of heat treatment and plant position}

Pre-storage heat treatment and packaging the plant vertically had higher visual quality as compared with untreated control in the first season. While no significant difference was detected in the second season (Table, 4). Four minutes dip at $47^{\circ} \mathrm{C}$ was partially effective in controlling extension growth but, the 6-min dip in water at $55^{\circ} \mathrm{C}$ were much more effective. At the same time the re-growth of trimmed leaves was highly variable in untreated control. Similar results were reported by Cantwell et al., (2001) on green onion plants.

The heat treatment at $\left(47^{\circ} \mathrm{C}\right.$ for 4 min reduced the rate of curvature of the green onion, whereas, those plants dipped into $55^{\circ} \mathrm{C}$ for 6 min or a vertically position in carton box effectively controlled subsequent green onion leaf curvature as compared with the un treated plants in the two seasons. Various metabolic reactions and growth phenomena can be controlled by short heat shock treatments (Hong et al, 2000 on green onion and Cantwell et al., 2003 on garlic).

It was demonstrated that curvature in green asparagus spear can be prevented by dipping the spears in $47^{\circ} \mathrm{C}$ for $2.5 \mathrm{~min}$. hot water or packaging the spear vertically Paull and Chen (1999). Untreated control and a- vertically position showed higher dry matter content in both seasons (Table, 4).

Table 4. Effect of heat treatment and plant position on physical and chemical properties of green onion plants during storage in 2005-2006 and 20062007 seasons.

\begin{tabular}{|c|c|c|c|c|c|c|}
\hline Treatment & $\begin{array}{l}\text { Visual } \\
\text { quality } \\
\text { (score) }\end{array}$ & $\begin{array}{c}\text { Leaf } \\
\text { extention } \\
(\mathrm{mm})\end{array}$ & $\begin{array}{c}\text { Curvature } \\
\text { (score) }\end{array}$ & $\begin{array}{l}\text { Dry } \\
\text { matter } \\
(\%)\end{array}$ & $\begin{array}{c}\text { Chlorophyll } \\
\text { (spad) }\end{array}$ & $\begin{array}{c}\text { Titratable } \\
\text { acidity } \\
\text { (mg/100g.f.w) }\end{array}$ \\
\hline \multicolumn{7}{|c|}{$2005-2006$} \\
\hline $55^{\circ} \mathrm{C} / 6 \mathrm{~min}$ & 7.39 & 0.34 & 1.40 & 12.82 & 43.19 & 0.22 \\
\hline $47^{\circ} \mathrm{C} / 4 \mathrm{~min}$ & 7.13 & 0.84 & 1.73 & 12.92 & 44.56 & 0.22 \\
\hline A-Vertically position & 6.86 & 1.58 & 1.07 & 13.34 & 43.17 & 0.22 \\
\hline Un-treated (control) & 6.46 & 1.82 & 2.67 & 13.15 & 42.80 & 0.21 \\
\hline L.S.D at $5 \%$ & 0.66 & 0.25 & 0.23 & 0.44 & N.S & 0.000233 \\
\hline \multicolumn{7}{|c|}{$2006-2007$} \\
\hline $55^{\circ} \mathrm{C} / 6 \mathrm{~min}$ & 7.19 & 0.12 & 1.53 & 12.26 & 46.72 & 0.23 \\
\hline $47^{\circ} \mathrm{C} / 4 \min$ & 6.86 & 1.06 & 2.20 & 12.44 & 47.39 & 0.24 \\
\hline A-Vertically position & 6.86 & 1.43 & 1.27 & 13.20 & 45.64 & 0.23 \\
\hline Un-treated (control) & 6.59 & 1.71 & 2.93 & 12.81 & 44.81 & 0.22 \\
\hline L.S.D at $5 \%$ & N.S & 0.49 & 0.23 & 0.40 & N.S & N.S \\
\hline
\end{tabular}


Pre-storage heat treatment and a- vertically position did not have any significant differences in their effects on the chlorophyll content in both seasons. Untreated control had lower values of titratable acidity as compared with the other treatments in the first season (Table, 4) but no significant difference was found in the second season.

\subsection{2: Effect of storage period.}

Green onion plant could be stored for 8 days at $0^{\circ} \mathrm{C}$ plus 2-subsequent days at $20^{\circ} \mathrm{C}$ without serious loss of quality. Significant loss of quality was observed when the period of storage was extended.

Storage green onion at $0^{\circ} \mathrm{C}$ for 8 days plus subsequence 2- days at $20^{\circ} \mathrm{C}$ results in $0.83 \mathrm{~mm}$ leaf extension of the cut end,. Moreover, a continuous increases in leaf extension were evident where storage period was extended to 16 days at $0^{\circ} \mathrm{C}$ plus 2- subsequence days at $20^{\circ} \mathrm{C}$, and leaf growth reached $2.81 \mathrm{~mm}$ in the first season (Table, 5). Such an increase in leaf extension, negatively affected the market quality (Hong et $\mathrm{al}, 2000$ ). It was noticed that temperature over $0^{\circ} \mathrm{C}$ favored leaf growth of asparagus spears in addition storage under conventional had influences since the apex cells were kept in a state of active division and consequently inner petioles continued to grow and elongate (Paull and Chen 1999).

The leaf curvature started to be shown after 8 days of cold storage plus 2subsequent days at $20^{\circ} \mathrm{C}$, extending the period of storage up to 16 days at $0^{\circ} \mathrm{C}$ plus 2 days at $20^{\circ} \mathrm{C}$ resulted in a significant higher leaf curvature score (Table 5).

Table 5. Effect of storage period on physical and chemical properties of green onion plants during storage in 2005-2006 and 2006-2007 seasons.

\begin{tabular}{|c|c|c|c|c|c|c|}
\hline $\begin{array}{r}\text { Storage period } \\
\text { (days) }\end{array}$ & $\begin{array}{l}\text { Visual } \\
\text { quality } \\
\text { (score) }\end{array}$ & $\begin{array}{l}\text { Leaf } \\
\text { extention } \\
(\mathrm{mm})\end{array}$ & $\begin{array}{l}\text { Curvature } \\
\text { (score) }\end{array}$ & $\begin{array}{l}\text { Dry } \\
\text { matter } \\
(\%)\end{array}$ & $\begin{array}{c}\text { Chlorophyll } \\
\text { (spad) }\end{array}$ & $\begin{array}{l}\text { Titratable } \\
\text { acidity } \\
\text { (mg/100g.f.w) }\end{array}$ \\
\hline \multicolumn{7}{|c|}{ 2005-2006 } \\
\hline At harvest & 9.00 & 0.00 & 1.00 & 13.63 & 51.40 & 0.26 \\
\hline $4 \mathrm{~d}$ at $0^{\circ} \mathrm{C}+2 \mathrm{~d}$ at $20^{\circ} \mathrm{C}$ & 7.66 & 0.37 & 1.00 & 13.57 & 46.55 & 0.23 \\
\hline $8 \mathrm{~d}$ at $0^{\circ} \mathrm{C}+2 \mathrm{~d}$ at $20^{\circ} \mathrm{C}$ & 7.00 & 0.83 & 1.66 & 13.13 & 43.43 & 0.22 \\
\hline $12 \mathrm{~d}$ at $0^{\circ} \mathrm{C}+2 \mathrm{~d}$ at $20^{\circ} \mathrm{C}$ & 6.00 & 1.72 & 2.08 & 12.71 & 39.55 & 0.20 \\
\hline $16 \mathrm{~d}$ at $0^{\circ} \mathrm{C}+2 \mathrm{~d}$ at $20^{\circ} \mathrm{C}$ & 5.16 & 2.81 & 2.84 & 12.24 & 36.22 & 0.18 \\
\hline L.S.D at $5 \%$ & 0.73 & 0.28 & 0.26 & 0.49 & 3.351 & 0.000261 \\
\hline \multicolumn{7}{|c|}{$2006-2007$} \\
\hline At harvest & 9.00 & 0.00 & 1.00 & 12.89 & 54.70 & 0.27 \\
\hline $4 \mathrm{~d}$ at $0^{\circ} \mathrm{C}+2 \mathrm{~d}$ at $20^{\circ} \mathrm{C}$ & 7.75 & 0.40 & 1.08 & 13.08 & 48.75 & 0.24 \\
\hline $8 \mathrm{~d}$ at $0^{\circ} \mathrm{C}+2 \mathrm{~d}$ at $20^{\circ} \mathrm{C}$ & 7.33 & 0.89 & 1.83 & .12 .86 & 45.77 & 0.23 \\
\hline $12 \mathrm{~d}$ at $0^{\circ} \mathrm{C}+2 \mathrm{~d}$ at $20^{\circ} \mathrm{C}$ & 5.99 & 1.52 & 2.66 & 12.47 & 41.93 & 0.21 \\
\hline $16 \mathrm{~d}$ at $0^{\circ} \mathrm{C}+2 \mathrm{~d}$ at $20^{\circ} \mathrm{C}$ & 4.33 & 2.59 & 3.33 & 12.09 & 39.55 & 0.20 \\
\hline L.S.D at $5 \%$ & 0.70 & 0.55 & 0.26 & 0.45 & 3.85 & 0.026 \\
\hline
\end{tabular}


A significant loss of dry matter, chlorophyll and titratable acidity were detected with the extended of the storage period and reached the lowest values by the end of 16 days at $0^{\circ} \mathrm{C}$ plus 2- subsequent days at $20^{\circ} \mathrm{C}$ (Table, 5).

\subsubsection{Effect of interaction among heat treatment, plant position and storage} period.

Interaction effect among heat treatment, plant position $\mathrm{x}$ storage period appeared significant for the physical and chemical quality attributes, (Table, 6). The obtained results showed that, after 16 days at $0^{\circ} \mathrm{C}$ plus 2 - days at $20^{\circ} \mathrm{C}$, the interaction among all the studied factors were found significant for visual quality, dry matter, chlorophyll and titratable acidity,. However, hot water dips at $55^{\circ} \mathrm{C}$ for 6 min. gave the lowest leaf growth (1.20) mm after 16 days of cold storage plus 2- days at $20^{\circ} \mathrm{C}$, whereas, untreated control and a-vertically position had the highest values of leaf growth over the same period in the two season.

After 16 days of cold storage followed by 2 - days at $20^{\circ} \mathrm{C}$ a-vertically position had lower curvature score, whereas untreated control showed the higher values over the same period in the two seasons (Table, 6), From the previous results, it could be suggested that dipping the white leaf bases of green onion in hot water at $55^{\circ} \mathrm{C}$ for 6 min., effectively controlled leaf growth of the green onion, reduced geotropic curvature and gave good appearance after 12 days at $0^{\circ} \mathrm{C}$ plus 2-days at $20^{\circ} \mathrm{C}$. 
Table 6. Effect of interaction between heat treatment, plant position and storage period on physical and chemical properties of green onion plants during storage in 2005-2006 and 2006-2007 seasons.

\begin{tabular}{|c|c|c|c|c|c|c|c|c|c|c|c|c|c|}
\hline \multirow{2}{*}{ 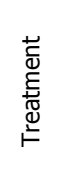 } & \multirow{2}{*}{$\begin{array}{l}\text { storage period } \\
\text { (days) }\end{array}$} & $\begin{array}{l}\text { Visual } \\
\text { quality } \\
\text { (score) }\end{array}$ & $\begin{array}{l}\text { Leaf } \\
\text { extension } \\
(\mathrm{mm})\end{array}$ & $\begin{array}{l}\text { Curvature } \\
\text { (score) }\end{array}$ & $\begin{array}{c}\text { Dry } \\
\text { matter } \\
(\%)\end{array}$ & $\begin{array}{l}\text { Chlorophyll } \\
\text { (spad) }\end{array}$ & $\begin{array}{c}\text { Titratable } \\
\text { acidity } \\
\text { (mg/100g.f.w) }\end{array}$ & $\begin{array}{l}\text { Visual } \\
\text { quality } \\
\text { (score) }\end{array}$ & $\begin{array}{l}\text { Leaf } \\
\text { extension } \\
(\mathrm{mm})\end{array}$ & $\begin{array}{c}\text { Curvature } \\
\text { (score) }\end{array}$ & $\begin{array}{c}\text { Dry } \\
\text { matter } \\
(\%)\end{array}$ & $\begin{array}{l}\text { Chlorophyll } \\
\text { (spad) }\end{array}$ & $\begin{array}{c}\text { Titratable } \\
\text { acidity } \\
\text { (mg/100g.f.w) }\end{array}$ \\
\hline & & \multicolumn{6}{|c|}{$2005-2006$} & \multicolumn{6}{|c|}{$2006-2007$} \\
\hline \multirow{5}{*}{ 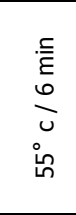 } & At harvest & 9.00 & 0.00 & 1.00 & 13.63 & 51.40 & 0.26 & 9.00 & 0.00 & 1.00 & 12.89 & 54.70 & 0.27 \\
\hline & $4 \mathrm{~d}$ at $0^{\circ} \mathrm{C}+2 \mathrm{~d}$ at $20^{\circ} \mathrm{C}$ & 8.33 & 0.00 & 1.00 & 13.21 & 45.50 & 0.23 & 8.00 & 0.00 & 1.00 & 12.67 & 49.00 & 0.25 \\
\hline & $8 \mathrm{~d}$ at $0^{\circ} \mathrm{C}+2 \mathrm{~d}$ at $20^{\circ} \mathrm{C}$ & 7.66 & 0.00 & 1.00 & 12.86 & 43.60 & 0.22 & 7.66 & 0.00 & 1.00 & 12.31 & 46.20 & 0.23 \\
\hline & $12 \mathrm{~d}$ at $0^{\circ} \mathrm{C}+2 \mathrm{~d}$ at $20^{\circ} \mathrm{C}$ & 6.33 & 0.51 & 1.66 & 12.45 & 39.40 & 0.20 & 6.33 & 0.00 & 2.00 & 11.91 & 42.90 & 0.22 \\
\hline & $16 \mathrm{~d}$ at $0^{\circ} \mathrm{C}+2 \mathrm{~d}$ at $20^{\circ} \mathrm{C}$ & 5.66 & 1.20 & 2.33 & 11.94 & 36.03 & 0.18 & 5.00 & 0.59 & 2.66 & 11.53 & 40.80 & 0.21 \\
\hline \multirow{5}{*}{ 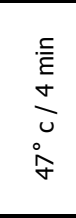 } & At harvest & 9.00 & 0.00 & 1.00 & 13.63 & 51.40 & 0.26 & 9.00 & 0.00 & 1.00 & 12.89 & 54.70 & 0.27 \\
\hline & $4 \mathrm{~d}$ at $0^{\circ} \mathrm{C}+2 \mathrm{~d}$ at $20^{\circ} \mathrm{C}$ & 7.66 & 0.00 & 1.00 & 13.36 & 48.20 & 0.24 & 7.66 & 0.33 & 1.00 & 12.90 & 50.80 & 0.25 \\
\hline & $8 \mathrm{~d}$ at $0^{\circ} \mathrm{C}+2 \mathrm{~d}$ at $20^{\circ} \mathrm{C}$ & 7.00 & 0.00 & 1.66 & 12.92 & 44.80 & 0.22 & 7.66 & 0.62 & 2.00 & 12.50 & 47.43 & 0.24 \\
\hline & $12 \mathrm{~d}$ at $0^{\circ} \mathrm{C}+2 \mathrm{~d}$ at $20^{\circ} \mathrm{C}$ & 6.33 & 1.67 & 2.00 & 12.54 & 41.20 & 0.21 & 5.66 & 1.66 & 3.33 & 12.12 & 42.40 & 0.21 \\
\hline & $16 \mathrm{~d}$ at $0^{\circ} \mathrm{C}+2 \mathrm{~d}$ at $20^{\circ} \mathrm{C}$ & 5.66 & 2.53 & 3.00 & 12.13 & 37.20 & 0.19 & 4.33 & 2.69 & 3.66 & 11.81 & 41.60 & 0.21 \\
\hline \multirow{5}{*}{ 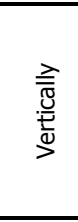 } & At harvest & 9.00 & 0.00 & 1.00 & 13.63 & 51.40 & 0.26 & 9.00 & 0.00 & 1.00 & 12.89 & 54.70 & 0.27 \\
\hline & $4 \mathrm{~d}$ at $0^{\circ} \mathrm{C}+2 \mathrm{~d}$ at $20^{\circ} \mathrm{C}$ & 7.66 & 0.71 & 1.00 & 13.96 & 46.30 & 0.23 & 7.66 & 0.59 & 1.00 & 13.42 & 47.80 & 0.24 \\
\hline & $8 \mathrm{~d}$ at $0^{\circ} \mathrm{C}+2 \mathrm{~d}$ at $20^{\circ} \mathrm{C}$ & 7.00 & 1.50 & 1.00 & 13.46 & 42.50 & 0.21 & 7.00 & 1.33 & 1.00 & 13.63 & 45.40 & 0.23 \\
\hline & $12 \mathrm{~d}$ at $0^{\circ} \mathrm{C}+2 \mathrm{~d}$ at $20^{\circ} \mathrm{C}$ & 5.66 & 2.10 & 1.00 & 13.06 & 39.30 & 0.20 & 6.33 & 2.10 & 1.33 & 13.23 & 41.70 & 0.21 \\
\hline & $16 \mathrm{~d}$ at $0^{\circ} \mathrm{C}+2 \mathrm{~d}$ at $20^{\circ} \mathrm{C}$ & 5.00 & 3.60 & 1.33 & 12.58 & 36.33 & 0.18 & 4.33 & 3.11 & 2.00 & 12.83 & 38.60 & 0.19 \\
\hline \multirow{5}{*}{ 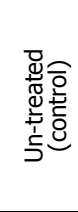 } & At harvest & 9.00 & 0.00 & 1.00 & 13.63 & 51.40 & 0.26 & 9.00 & 0.00 & 1.00 & 12.89 & 54.70 & 0.27 \\
\hline & $4 \mathrm{~d}$ at $0^{\circ} \mathrm{C}+2 \mathrm{~d}$ at $20^{\circ} \mathrm{C}$ & 7.00 & 0.77 & 1.00 & 13.75 & 46.20 & 0.23 & 7.66 & 0.66 & 1.33 & 13.33 & 47.40 & .0 .24 \\
\hline & $8 \mathrm{~d}$ at $0^{\circ} \mathrm{C}+2 \mathrm{~d}$ at $20^{\circ} \mathrm{C}$ & 6.33 & 1.80 & 3.00 & 13.28 & 42.80 & 0.21 & 7.00 & 1.60 & 3.33 & 13.00 & 44.03 & 0.22 \\
\hline & $12 \mathrm{~d}$ at $0^{\circ} \mathrm{C}+2 \mathrm{~d}$ at $20^{\circ} \mathrm{C}$ & 5.66 & 2.61 & 3.66 & 12.78 & 38.30 & 0.19 & 5.66 & 2.33 & 4.00 & 12.63 & 40.70 & 0.20 \\
\hline & $16 \mathrm{~d}$ at $0^{\circ} \mathrm{C}+2 \mathrm{~d}$ at $20^{\circ} \mathrm{C}$ & 4.33 & 3.90 & 4.70 & 12.31 & 35.30 & 0.18 & 3.66 & 3.96 & 5.00 & 12.21 & 37.20 & 0.19 \\
\hline $\begin{array}{l}\text { L.S.D } \\
\text { at } 5 \%\end{array}$ & & 1.47 & 0.57 & 0.52 & 0.98 & 6.70 & 0.000522 & 1.41 & 1.10 & 0.52 & 0.91 & 7.71 & 0.05 \\
\hline
\end{tabular}




\section{REFERENCES}

1. Atta-Aly, M. A. 1998. Effect of hydro-cooling and polyethylene package lining on maintaining green onion quality for export. Annals of Agricultural Nal Science 43 (1): 231-249.

2. Artes, F, V. H. Escalona, F. Artes- Hdez. 2002. Quality and physiological changes of fennel under controlled atmosphere storage. Eur. Food Res. Technol., 21: 216 $-220$.

3. A.O.A.C. 1990. Association of Official Agriculture Chemist Official Methods of Analysis of A.O.A.C. $12^{\text {th }}$ Ed. Washington DC.

4. Cantwell, M. I., G. Hong and T. V. Suslow. 2001. Heat treatments control extension growth and enhance microbial disinfection of minimally processed green onion. Hortscince 36 (4): $732-737$.

5. Cantwell, M. I., J. Kang and G. Hong. 2003. Heat treatment control sprouting and rooting of garlic cloves. Post-harvest Biology and Technology, 30: 57 - 65.

6. Emam, M. S. 1999. Effect of some post-harvest treatments on the storage and quality of green onion. Ph.D. Thesis, Fac. Agric. Ain Shams Uni.

7. Hong, G., G. Peisen and M. I. Cantwell. 2000. Use of controlled atmosphere and heat treatment to maintain quality of intact and minimally processed green onion. Post- harvest Biology and Technology, 20: 53 - 61.

8. Hruschka, H. W. 1974. Storage and shelf life of packaged green onions U.S. Dept. Agr. Market. Res. Rpt., 1015.

9. Hulme, A. C. 1970. The biochemistry of fruit and their products. Academic Press London and New York. Vol. 1.

10. In, H. S. and K. D. Man. 2004. The effect of packaging treatment on the storage quality of minimally processed bunched onion. International Jour. of Food Science and Technology 39 (10): $1033-1041$.

11. Jacxsens, L., F. Devlieghere and J. Debevere. 2002. Temperature dependence of shelf life as affected by microbial proliferation and sensory quality of equilibrium modified atmosphere packaged fresh produce. Post-harvest Biology and Technology, 26: $59-73$.

12. Paull, R.E. and N. J. Chen. 1999. Heat treatment prevents post-harvest geotropic curvature of asparagus spears ( Asparagus officinalis L.). Post-harvest Biology and Technology 16, $37-41$.

13. Snedercor, G. W. and W. G. Cochran. .1980. 'Statistical Methods ' $6^{\text {th }}$ (ed). Iowa State University Preu , Am. Iowa, USA. 
تأثير إستخدام المغلفات والمعاملة الحرارية فى الحفاظ على جودة البصل الاخضر

$$
\text { مصطقى صالح إمام }
$$

$$
\text { قسم بحوث تداول الخضر - معهد بحوث البساتين - مركز البحوث الزراعية - جيزة }
$$

اختبرت المغلفات والمعاملة الحرارية كطرق للحفاظ على جودة البصل الاخضر ولإطالة فترة

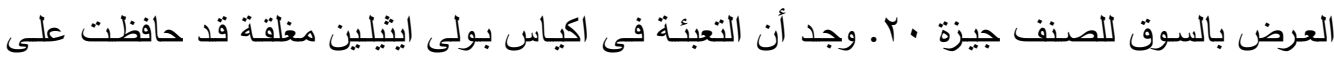

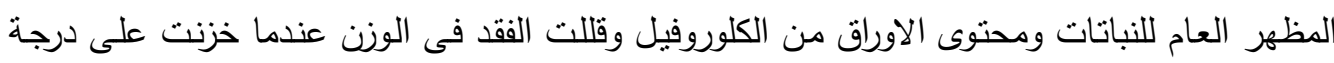
حرارة صفر درجة مئوية يتبعها يومين على درجة حرارة • ب درجة مئوية (كفترة عرض بالاسواق) ولكنها

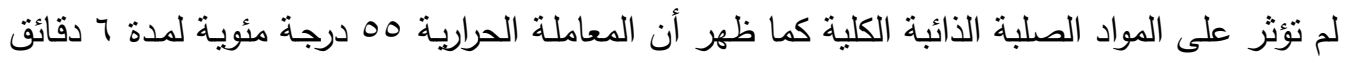
قد ثبطت من استطالة الأوراق وقللت الانحناء ووضتح أن وضع النباتات رأسياُ داخل الكرنونـة يقلل من دنه انحناء النباتات لكنة لم يؤثز على الاسنطالة. 